УДК 338.2

\title{
ПРИРОДНО-СЫРЬЕВОЙ ПОТЕНЦИАЛ КАК ФАКТОР КОНКУРЕНТОСПОСОБНОСТИ РОССИЙСКОЙ ЭКОНОМИКИ
}

\author{
Смирнов Алексей Юрьевич \\ Д.э.н., доценТ \\ Санкт-Петербургский государственный \\ морской технический университет
}

Аннотация: В статье анализируется влияние природно-сырьевого потенциала на уровень конкурентоспособности экономики Российской Федерации в краткосрочной и долгосрочной перспективах. Особое внимание уделено проблеме рационального использования экспортных доходов с целью обеспечения устойчивого роста национальной экономики.

Ключевые слова: конкурентоспособность, природные ресурсы, ресурсный потенциал, российская экономика.

\section{NATURAL RESOURCE POTENTIAL AS A FACTOR OF COMPETITIVENESS OF THE RUSSIAN ECONOMY}

\section{Smirnov Aleksey Yur'yevich}

\begin{abstract}
The article analyzes the impact of natural resource potential on the level of competitiveness of the Russian economy in the short and long term. Special attention is paid to the problem of rational use of export revenues in order to ensure sustainable growth of the national economy.

Key words: competitiveness, natural resources, resource potential, Russian economy.

В научной и популярной литературе можно встретить тезис о том, что Российская Федерация обладает существенными конкурентными преимуществами за счет высокого природно-сырьевого потенциала. Данное положение нуждается в подробном экономическом анализе и корректировке с учетом реальных условий функционирования национальной экономической системы нашей страны.
\end{abstract}

Неоспоримым является тот факт, что Россия обладает огромными 26 
запасами природных ресурсов, что позволяет стране получать существенные доходы от экспорта. В краткосрочном плане такое преимущество представляется бесспорным, но в долгосрочном плане, богатая сырьевая база может стать фактором, отрицательно влияющим на конкурентоспособность страны по следующим причинам.

Низкая стоимость природных ресурсов препятствует внедрению энергосберегающих технологий. Нет никакой необходимости внедрять новые технологии в условиях, когда ресурсы стоят дешево. Одновременно не возникает необходимости проводить природоохранные мероприятия, когда штрафы за загрязнение окружающей среды малы. Исключением является штраф в 146 млрд. руб., который выплатил «Норильский никель» за разлив топлива под Норильском в мае 2020 года. В результате не только наносится ущерб экологии местности, что оказывает отрицательное влияние на воспроизводство трудовых ресурсов, но и замедляются темпы экономического роста. Ведь инвестиции в ресурсосберегающие технологии не только приводят к появлению новых предприятий и рабочих мест, но и способствуют развитию науки. Научные открытия, сделанные для целей ресурсосбережения, могут быть использованы и в других сферах деятельности. Тем самым средства, которые могли бы быть направлены в наукоемкие отрасли экономики, либо направляются в бюджет в виде штрафов за превышение выбросов в атмосферу, либо выплачиваются производителям ресурсов, которые не заинтересованы в научно-техническом прогрессе.

В результате ошибочно проведенной приватизации минеральносырьевые ресурсы России поделены между отдельными экономическими группами, получившими в обществе название олигархов. Поскольку социально-экономическая обстановка в России не стабильна, то олигархи, часть которых виновна в нарушении экономического законодательства в прошлом, стремятся вывезти средства, полученные от реализации природных ресурсов из страны. Для этого используются разнообразные схемы, причем перекрыть полностью каналы вывоза валюты невозможно, поскольку введение новых ограничений негативно повлияет на деятельность легальных экспортеров и импортеров. Весьма показателен тот факт, что российские нефтяные компании, постоянно «жалуются» общественности на высокие налоги, которые якобы препятствуют обновлению основных фондов, что в ближайшем будущем может привести к уменьшению добычи нефти.

Таким образом, приходится констатировать, что значительная часть прибыли от использования минерально-сырьевых ресурсов России используется не для повышения конкурентоспособности экономики в 
стратегическом периоде времени, а для инвестиций в экономику других государств.

Но самое главное заключается в том, что в современной экономике наличие природно-сырьевых ресурсов уже не является условием экономического роста. Материало- и энергоемкость промышленности развитых государств постоянно падает. В 80-90-е годы XX века произошло существенное сокращение реальной стоимости всех природно-сырьевых ресурсов за исключением, пожалуй, палладия. Цены на нефть в долгосрочной перспективе снижаются под влиянием активного использования новых технологий. В 2020 году наблюдался их критический обвал. В 2021 году напротив наблюдается корректировка нефтяных цен, но ее продолжительность является дискуссионной. Примеры таких стран, как Япония, Тайвань, Сингапур, Гонконг, Южная Корея, Люксембург свидетельствует о том, что не природно-сырьевые, а трудовые, финансовые и информационные ресурсы являются главным фактором обеспечения конкурентоспособности экономики в современном мире. В ведущих промышленных державах после мирового энергетического кризиса 1973 года наметилась устойчивая тенденция к сокращению энергоемкости создаваемой единицы ВВП. В результате принятия мер по сохранению и рациональному использованию энергии энергоемкость единицы ВВП в промышленно развитых странах снизилась на 22\%, при этом нефтеемкость - почти на $38 \%$. В России прослеживается противоположная тенденция. За период с 1990 по 1999 год энергоемкость ВВП России увеличилась на 31\%. В последующий период наблюдается снижение данного показателя.

Однако в краткосрочной перспективе наличие природно-сырьевых ресурсов может реально способствовать получению необходимых валютных поступлений. В этом отношении положение России представляется предпочтительным, например, по сравнению с Украиной, которая находится в сходной экономической ситуации. Проблема заключается в том, сможет ли государство создать такие условия экономической деятельности в стране, чтобы полученные от продажи минеральных ресурсов средства были бы направлены на инвестиции в наиболее прогрессивные и быстрорастущие секторы экономики, способные обеспечить высокие темпы экономического роста в долгосрочной перспективе.

Отрицательное влияние на конкурентоспособность предприятий сырьевого сектора экономики оказывает экономическая нестабильность в виде отсутствия четких и неизменных правил рыночных взаимоотношений. 
Постоянные изменения налогового и бухгалтерского законодательства служат серьезным препятствием для иностранных инвесторов. Правительством предприняты правильные шаги с тем, чтобы обеспечить стабильность экономического законодательства путем принятия основополагающих кодексов (Налоговый, Бюджетный, Земельный и др). Обеспечение экономической стабильности также является важнейшим фактором, способствующим увеличению внутренних инвестиций. Пока не будет обеспечена экономическая стабильность, радикально решить проблему вывоза капиталов за рубеж не удастся.

В то же время в системе налогообложения сырьевых товаров наблюдаются негативные тенденции. Так, происходят негативные изменения в системе налогообложения нефтяных компаний, вводятся квоты на экспорт продовольствия, что негативным образом сказывается на привлекательности данных структурных составляющих национальной экономики.

Таким образом, природно-сырьевой потенциал национальной экономики является одним из важных факторов, обеспечивающих рост ее конкурентоспособности с краткосрочной перспективе. В долгосрочной перспективе многое будет определяться теми управленческими решениями, которые направлены на перераспределение полученных доходов от экспорта ресурсов между другими секторами национальной экономики.

\section{Список литературы}

1. Абрамов В. Управление конкурентоспособностью экономических систем / В. Абрамов // Маркетинг. - 2004. - №5. - С. 19-24.

2. Андрианов В. Конкурентоспособность России в мировой экономике / В. Андрианов // Мировая экономика и международные отношения. - 2000. №3. - С. 47-57

3. Васильева 3.А. Иерархия понятий конкурентоспособности субъектов рынка / 3.А. Васильева // Маркетинг в России и за рубежом. - 2006. - №2. C. 83-90.

4. Гельвановский М. Обеспечение лидерства России через рост конкурентоспособности / М. Гельвановский, А.Захаров // Экономист. - 2014. N 11. - C.48-57.

5. Кондратьев В. Макроэкономические проблемы конкурентоспособности России // Мировая экономика и междунар. отношения. - 2001. - N 3. - С.54-60.

6. Кондратьев В. Минерально-сырьевые ресурсы как фактор глобальной конкурентоспособности // Мировая экономика и междунар. отношения. - 2010. - N 6. - C.20-30. 